\title{
PENERAPAN MODEL PEMBELAJARAN PROBLEM BASED LEARNING UNTUK MENINGKATKAN KEAKTIFAN BELAJAR SISWA PADA MATERI EKOSISTEM DI KOMPETENSI KEAHLIAN X OTOMATISASI DAN TATA KELOLA PERKAANTORAN SMKN 2 PENAJAM PASER UTARA TAHUN PELAJARAN 2017/2018
}

\author{
Susilowati \\ SMK N 2 PPU \\ susilowatismkn2@gmail.com
}

\begin{abstract}
ABSTRAK
Karakter siswa di kompetensi keahlian X Otomatisasi dan Tata kelola Perkantoran SMKN 2 Penajam Paser Utara untuk materi ekosistem sebelumnya kurang aktif dalam pembelajaran IPA Terapan, hal ini ditunjukkan dengan kurangnya respon siswa kepada materi pelajaran, siswa cenderung pasif dalam pembelajaran. Penelitian ini bertujuan untuk meningkatkan keaktifan belajar siswa melalui penerapan model pembelajaran Problem Based Learning. Jenis penelitian ini adalah Penelitian Tindakan Kelas (PTK) yang dilaksanakan dalam dua siklus. Setiap siklus terdiri dari beberapa tahap yaitu perencanaan, pelaksanaan tindakan, observasi dan refleksi. Subjek dalam penelitian ini adalah siswa di kompetensi keahlian X Otomatisasi dan Tata Kelola Perkantoran Tahun pelajaran 2017/2018 yang terdiri atas 31 siswa. Teknik utama dalam pengumpulan data dilakukan dengan cara observasi, angket dan dokumentasi. Hasil penelitian menunjukkan bahwa pada siklus I rata-rata prosentase keaktifan belajar siswa adalah 74\%. Pada siklus II prosentase keaktifan belajar siswa adalah 85\%. Berdasarkan data prosentase tiap siklus ternyata terjadi kenaikan keaktifan belajar siswa. Kesimpulan penelitian ini adalah bahwa model pembelajaran Problem Based Learning (PBL) dapat meningkatkan keaktifan belajar siswa pada materi ekosistem di kompetensi keahlian X Otomatisasi dan Tata kelola Perkantoran SMK N 2 Penajam Paser Utara, Tahun Pelajaran 2017/2018
\end{abstract}

Kata Kunci : Model Pembelajaran Problem Based Learning (PBL), Keaktifan Belajar Siswa, Ekosistem

\section{PENDAHULUAN}

Proses pembelajaran dikatakan efektif bila peserta didik secara aktif ikut terlibat langsung dalam pengorganisasian dan penemuan informasi (pengetahuan), sehingga mereka tidak hanya menerima secara pasif pengetahuan yang diberikan oleh guru.

Sekolah adalah salah satu pusat kegiatan belajar. Dengan demikian di sekolah merupakan arena untuk mengembangkan aktivitas siswa. Keadaan dimana siswa melakukan aktivitas belajar inilah yang disebut keaktifan belajar.

Keaktifan siswa dalam proses pembelajaran akan menyebabkan interaksi yang tinggi antara guru dengan siswa ataupun siswa dengan siswa, yang menjadikan kelas menjadi segar dan kondusif, melibatkan kemampuannya semaksimal mungkin sehingga diharapkan adanya peningkatan penyerapan materi baik pengetahuan dan ketrampilan yang diajarkan, (Sardiman, 2005:96) 
Aktivitas belajar ditunjukkan dengan adanya ketertiban intelektual dan emosional yang tinggi dalam proses belajar. Siswa diberikan kesempatan untuk berdiskusi mengemukakan pendapat dan idenya, melakukan eksplorasi terhadap materi yang sedang dipelajari serta menafsirkan hasilnya secara bersama-sama di dalam kelompok. Kegiatan tersebut memungkinkan siswa berinteraksi aktif dengan lingkungan dan kelompoknya, sebagai media untuk mengembangkan kemampuannya (Djamarah, Syaiful Bahri, 2010: 362).

Karakter siswa di kompetensi keahlian X Otomatisasi dan Tata kelola Perkantoran SMKN 2 Penajam Paser Utara untuk materi sebelumnya kurang aktif dalam pembelajaran IPA Terapan, hal ini ditunjukkan dengan kurangnya respon siswa kepada materi pelajaran, siswa cenderung pasif dalam pembelajaran. Baik interaksi antar siswa maupun interaksi siswa dengan guru kurang. Usaha untuk merubah siswa yang pasif dan kurang respon tersebut maka penulis ingin mencoba melakukan penelitian untuk mengatasi masalah tersebut. Untuk itu penulis melakukan penelitian yang berjudul : Penerapan Model Problem Based Learning Untuk Meningkatkan Keaktifan Belajar Siswa pada Materi Ekosistem di Kompetensi Keahlian X Otomatisasi dan Tata Kelola Perkantoran SMKN 2 Penajam Paser Utara, Tahun Pelajaran 2017/2018

Tujuan dari penelitian ini adalah ingin mencari alternatif model pembelajaran yang dapat meningkatkan keaktifan siswa pada materi Ekosistem di kompetensi keahlian X Otomatisasi dan Tata kelola Perkantoran SMKN 2 Penajam Paser Utara.

\section{Pengertian Aktivitas Belajar}

Aktivitas belajar adalah aktivitas yang bersifat fisik ataupun mental.
Dalam proses pembelajaran, kedua aktivitas tersebut harus selalu terkait / tidak dapat dipisahkan. Seorang peserta didik akan berpikir selama ia berbuat, tanpa perbuatan maka peserta didik tidak berfikir. Oleh karena itu agar peserta didik aktif berfikir maka peserta didik harus diberi kesempatan untuk berbuat atau beraktivitas, (Sardiman, 2012:100).

Belajar sangat dibutuhkan adanya aktivitas, dikarenakan tanpa adanya aktivitas proses belajar tidak mungkin berlangsung dengan baik. Pada proses aktivitas pembelajaran harus melibatkan seluruh indikator peserta didik, baik jasmani maupun rohani sehingga perubahan perilakunya dapat berubah dengan cepat, tepat, mudah dan benar, baik berkaitan dengan indikator kognitif afektif maupun psikomotor (Nanang Hanafiah, 2010:23)

Oemar Hamalik (2009: 179) menyatakan bahwa aktivitas belajar merupakan kegiatan yang dilakukan oleh siswa dalam kegiatan pembelajaran. Aktivitas belajar dapat terwujud apabila siswa terlibat belajar secara aktif

Jadi aktivitas belajar merupakan kegiatan atau tindakan baik fisik maupun mental yang dilakukan oleh individu untuk membangun pengetahuan dan ketrampilan dalam diri dalam kegiatan pembelajaran. Aktivitas belajar akan menjadikan pembelajaran yang efektif. Guru tidak hanya menyampaikan pengetahuan dan ketrampilan saja. Namun, guru harus mampu membawa siswa untuk aktif dalam belajar.

\section{Jenis-jenis Aktivitas Belajar}

Paul B. Diedrich yang dikutip dalam Nanang hanafiah dan Cucu suhana (2010:24) menyatakan, aktivitas belajar dibagi ke dalam delapan kelompok, yaitu sebagai berikut: 
1) Kegiatan-kegiatan visual (visual activities), yaitu membaca, melihat gambar-gambar, mengamati eksperimen, demonstrasi, pameran dan mengamati orang lain bekerja atau bermain.

2) Kegiatan-kegiatan lisan (oral activities), yaitu mengemukakan suatu fakta atau prinsip, menghubungkan suatu kejadian mengajukan pertanyaan, memberi saran, mengemukakan pendapat, berwawancara diskusi dan interupsi

3) Kegiatan-kegiatan mendengarkan (listening activities), yaitu mendengarkan penyajian bahan, mendengarkan percakapan atau diskusi kelompok, atau mendengarkan radio.

4) Kegiatan-kegiatan menulis (writing activities), yaitu menulis cerita, menulis laporan, memeriksa karangan, bahan-bahan copy, membuat outline atau rangkuman, dan mengerjakan tes serta mengisi angket.

5) Kegiatan-kegiatan menggambar (drawing activities), yaitu menggambar, membuat grafik, diagram, peta dan pola.

6) Kegiatan-kegiatan motorik (motor activities), yaitu melakukan percobaan, memilih alat-alat, melaksanakan pameran, membuat model, menyelenggarakan permainan, serta menari dan berkebun.

7) Kegiatan-kegiatan mental (mental activities), yaitu merenungkan mengingat, memecahkan masalah, menganalisa faktor-faktor, melihat hubungan-hubungan, dan membuat keputusan.

8) Kegiatan-kegiatan emosional (emotional activities), yaitu minat, membedakan, berani, tenang, merasa bosan dan gugup.
Berdasarkan uraian yang dikemukakan oleh para ahli mengenai aktivitas belajar, maka aktivitas belajar siswa dapat dilihat dan dinilai dalam indikator penelitian yang disusun oleh peneliti sebagai berikut : (1) Menyimak guru, (2) Aktif bertanya (3) Diskusi kelompok, (4) Menyelesaikan laporan, (5) Mengumpulkan data (6) Melakukan percobaan, (7) Aktif menjawab Menyimpulkan.

\section{Model Pembelajaran Problem Based Learning (PBL)}

Delisle dalam Abidin (2014: 159) menyatakan bahwa model PBL merupakan model pembelajaran yang dikembangkan untuk membantu guru mengembangkan kemampuan berfikir dan keterampilan memecahkan masalah pada siswa selama mereka mempelajari materi pembelajaran. Model ini memfasilitasi siswa untuk berperan aktif di dalam kelas melalui aktivitas memikirkan masalah yang berhubungan dengan kehidupan sehari-harinya, menemukan prosedur yang diperlukan untuk menemukan informasi yang dibutuhkan, memikirkan situasi konstektual, memecahkan masalah, dan menyajikan solusi masalah tersebut.

Kemendikbud (2013b) dalam Abidin (2014: 159) memandang model PBL suatu model pembelajaran yang menantang peserta didik untuk "belajar bagaimana belajar", bekerja secara berkelompok untuk mencari solusi dari permasalahan dunia nyata. Masalah yang diberikan ini digunakan untuk mengikat peserta didik pada rasa ingin tahu pada pembelajaran yang dimaksud. Masalah diberikan kepada peserta didik sebelum peserta didik mempelajari konsep atau materi yang berkenaan dengan masalah yang harus dipecahkan.

Hal tersebut sejalan dengan pendapat Sudarman (2007:69), model pembelajaran Problem Based Learning 
atau pembelajaran berbasis masalah adalah pembelajaran yang menggunakan masalah dunia nyata sebagai konteks bagi peserta didik untuk belajar tentang cara berfikir kritis dan ketrampilan pemecahan masalah, serta untuk memperoleh pengetahuan dan konsep yang esensial dari materi belajar.

Problem Based Learning merupakan suatu pendekatan dimana masalah mengendalikan proses pembelajaran. Masalah diajukan agar pembelajaran menyadari bahwa mereka harus mempelajari beberapa pengetahuan baru sebelum mereka memecahkan masalah tersebut. Problem Based Learning berfokus pada penyajian suatu permasalahan kepada siswa, kemudian siswa diminta mencari pemecahannya melalui serangkaian penelitian dan investigasi berdasarkan teori, konsep prinsip yang dipelajari dari berbagai bidang ilmu. Permasalahan sebagai fokus, stimulus dan pemandu proses proses belajar. Sementara guru menjadi fasilitator dan pembimbing (Eveline \& Hartini, 2011 : 123)

Arends dalam Helly Prajitno \& Sri Mulyani (2008:43) menyatakan bahwa pembelajarn dengan Problem Based Learning membantu siswa mengembangkan ketrampilan berpikir dan ketrampilan mengatasi masalah, mempelajari peran-peran orang dewasa dan menjadi pelajar mandiri. Siswa memiliki kebebasan dalam menye lesaikan program pembelajaran.

Menurut Arends dalam Helly

Prajitno \& Sri Mulyani (2008:57),

sintaks untuk model Problem Based Learning (PBL) dapat disajikan seperti pada Tabel di bawah ini

\begin{tabular}{|c|c|}
\hline FASE & \\
\hline $\begin{array}{l}\text { Fase } 1 \text { : } \\
\text { Memberiksn } \\
\text { orientasi } \\
\text { tentang } \\
\text { permasalahann }\end{array}$ & $\begin{array}{l}\text { Guru membahas tujuan } \\
\text { pembelajaran, } \\
\text { mendiskripsikan } \\
\text { berbagai kebutuhan } \\
\text { logistik penting, dan }\end{array}$ \\
\hline $\begin{array}{ll}\text { a } & \text { kep } \\
\text { eserta didi }\end{array}$ & $\begin{array}{l}\text { motivasi peserta didik } \\
\text { untuk terlibat dalam } \\
\text { kegiatan } \\
\text { masalah }\end{array}$ \\
\hline $\begin{array}{l}\text { Fase } 2 \text { : } \\
\text { Mengorganisa } \\
\text { sikan peserta } \\
\text { didik }\end{array}$ & $\begin{array}{l}\text { untuk } \\
\text { efinisikan dan } \\
\text { organisasikan } \\
\text {-tugas belajar yang } \\
\text { t dengan } \\
\text { asalahannya. }\end{array}$ \\
\hline $\begin{array}{l}\text { Fase } 3 \quad: \\
\text { Membantu } \\
\text { investigasi } \\
\text { mandiri dan } \\
\text { kelompok }\end{array}$ & $\begin{array}{l}\text { Guru mendorong peserta } \\
\text { didik untuk } \\
\text { mendapatkan informasi } \\
\text { yang } \\
\text { melaksanakan } \\
\text { eksperimen dan mencari } \\
\text { penjelasan dan solusi. }\end{array}$ \\
\hline $\begin{array}{l}\text { Fase } 4: \\
\text { Mengembangk } \\
\text { an dan } \\
\text { mempresentasi } \\
\text { kan hasil karya } \\
\text { dan } \\
\text { memamerkann } \\
\text { ya }\end{array}$ & $\begin{array}{l}\text { Guru membantu peserta } \\
\text { didik dalam } \\
\text { merencanakan dan } \\
\text { menyiapkan hasil karya } \\
\text { yang tepat, seperti } \\
\text { laporan dan membantu } \\
\text { mereka } \\
\text { menyampaikannya pada } \\
\text { orang lain }\end{array}$ \\
\hline $\begin{array}{l}\text { Fase } \quad 5 \\
\text { Menganalisis } \\
\text { dan } \\
\text { mengevaluasi } \\
\text { proses }\end{array}$ & $\begin{array}{lr}\text { didik untuk melakukan } \\
\text { refleksi } \quad \text { terhadap } \\
\text { penyelidikannya } \\
\text { proses-proses } & \text { dan } \\
\text { mereka gunakan } & \end{array}$ \\
\hline
\end{tabular}

Tabel 1. sintaks untuk model Problem Based Learning (PBL)

Jadi Problem Based Learning atau pembelajaran berbasis masalah adalah suatu strategi pembelajaran yang menggunakan masalah dunia nyata sebagai suatu konteks bagi peserta didik untuk belajar tentang cara berpikir kritis dan keterampilan pemecahan masalah, 
serta untuk memperoleh pengetahuan dan konsep yang esensial dari materi pelajaran.

\section{Ekosistem}

Ekosistem adalah sistem alam yang dibentuk dari interaksi antar mahluk hidup dengan lingkungannya. Ilmu yang mempelajari mengenai ekosistem adalah Ekologi. yaitu :

Komponen-komponen ekosistem

\section{Komponen biotik}

Biotik adalah istilah yang digunakan untuk menyebut suatu organisme. Komponen biotik merupakan suatu komponen yang menyusun ekosistem selain komponen abiotik. Komponen biotik yang tersusun dari seluruh mahluk hidup. Setiap mahluk hidup memiliki habitat dan relung. a) Habitat adalah tempat tinggal organisme di alam; b) Relung/Niche/Nisia fungsi atau peran suatu mahluk hidup dalam ekosistem.

Adapun tingkatan organisasi kehidupan yaitu:

1) Individu

Individu merupakan oranisme tunggal. Setiap individu berusaha mempertahankan hidupnya dengan beradaptasi melalui adaptasi morfologi, adaptasi fisiologi, adaptasi prilaku.

2) Populasi

Populasi adalah sekumpulan organisme dari satu spesies yang menempati kawasan tertentu.

\section{3) Komunitas}

Komunitas adalah kumpulan dari populasi-populasi yang menempati area dan wilayah tertentu dalam kurun waktu tertentu.

4) Ekosistem

Ekosistem adalah satuan fungsional antara mahluk hidup dengan lingkungannya yang dibedakan berdasarkan habitat dan fungsinya.
5) Bioma

Bioma adalah adalah kesatuan ekosistem dalam sekala luas.

6) Biosfer

Biosfer adalah seluruh ekosistem yang berada di seluruh permukaan bumi.

\section{Komponen abiotik}

Abiotik atau komponen tak hidup merupakan komponen fisik dan kimia yang medium atau substrat sebagai tempat berlangsungnya kehidupan atau lingkungan tempat hidup. Sebagian besar dari komponen abiotik memiliki beragam variasi dalam ruang dan waktu. Komponen abiotik berupa bahan organik, senyawa anorganik, serta faktor yang memengaruhi distribusi organisme, antara lain: suhu, air, garam, cahaya matahari, tanah dan batu, iklim, topografi dan angin

\section{Interaksi dalam ekosistem}

Dalam suatu ekosistem, komponen biotik dan abiotik saling berinteraksi dan berhubungan timbal balik. Macammacam interaksi dalam ekosistem yaitu Simbiosis dapat diartikan sebagai cara hidup bersama antara dua jenis makhluk hidup yang bersifat langsung dan erat. Terdapat beberapa bentuk simbiosis yaitu mutualisme, komensialisme, parasitesme, alelopati / antibiosis, predasi, protokooperasi. Tipe-tipe ekosistem yaitu akuatik (air), terestrial (darat), buatan.

\section{Aliran energi}

Aliran energi adalah jalur satu arah dari perubahan energi yang terjadi karena proses makan dimakan pada suatu ekosistem. Tingkat trofik adalah setiap kelompok organisme yang memiliki sumber makanan tertentu. Ada 5 tingkat trofik yaitu produsen, konsumen, detritivora, dekomposer. 


\section{Rantai makanan dan jaring-jaring makanan}

Rantai makanan adalah proses makan dan dimakan antara satu tingkat trofik dengan tingkat trofik lainnya membentuk urutan dengan arah tertentu.

Jaring-jaring makanan adalah hubungan makan dan dimakan yang kompleks yang saling bercabang dan berkaitan. Mieke Miarsyah(2008: 145)

\section{METODOLOGI PENELITIAN}

Metode yang digunakan dalam penelitian ini adalah penelitian tindakan kelas. Pendekatan yang digunakan dalam penelitian tindakan ini adalah pendekatan kualitatif. Penelitian ini dilakukan karena rendahnya keaktifan belajar siswa dalam kegiatan pembelajaran IPA Terapan. Permasalahan ini ditindaklanjuti dengan cara menerapkan sebuah model pembelajaran yang dapat meningkatkan keaktifan siswa dalam pembelajaran. Peneliti menggunakan model pembelajaran Problem Based Learning karena dianggap praktis dan cocok untuk materi ekosistem dan pembelajaran kurikulum 2013

Yang menjadi subjek dalam penelitian ini adalah siswa kompetensi keahlian X Otomatisasi dan Tata kelola Perkantoran, SMKN 2 penajam Paser Utara pada semester genap 2017/2018 pada materi Ekosistem yang dilaksanakan pada bulan Pebruari 2018.

\begin{tabular}{|l|l|l|}
\hline NO & AKTIVITAS & INDIKATOR \\
\hline 1 & Kegiatan Visual & $\begin{array}{l}\text { Menyimak } \\
\text { Guru }\end{array}$ \\
\hline 2 & Kegiatan Lisan & Aktif bertanya \\
\hline 3 & $\begin{array}{l}\text { Kegiatan } \\
\text { Mendengar }\end{array}$ & $\begin{array}{l}\text { Diskusi } \\
\text { kelompok }\end{array}$ \\
\hline 4 & Kegiatan Menulis & $\begin{array}{l}\text { Menyelesaikan } \\
\text { laporan }\end{array}$ \\
\hline 5 & $\begin{array}{l}\text { Kegiatan } \\
\text { menggambar }\end{array}$ & $\begin{array}{l}\text { Mengumpulkan } \\
\text { data }\end{array}$ \\
\hline 6 & Kegiatan metrik & $\begin{array}{l}\text { Melakukan } \\
\text { percobaan }\end{array}$ \\
\hline 7 & Kegiatan Mental & Aktif menjawab \\
\hline 8 & $\begin{array}{l}\text { Kegiatan } \\
\text { emosional }\end{array}$ & Menyimpulkan \\
\hline
\end{tabular}

Tabel 2. Aktivitas dan indicator penelitian oleh Nanang hanafiah dan Cucu suhana (2010:24)

\begin{tabular}{|c|c|c|c|}
\hline No & $\begin{array}{l}\text { Aspek } \\
\text { yang } \\
\text { diamati }\end{array}$ & Deskripsi & Indikator \\
\hline 1 & $\begin{array}{l}\text { Penda } \\
\text { huluan }\end{array}$ & $\begin{array}{l}\text { Kegiatan } \\
\text { guru dan } \\
\text { siswa saat } \\
\text { KBM }\end{array}$ & $\begin{array}{l}\text { a. Salam dan } \\
\text { Doa } \\
\text { b. Presensi } \\
\text { c.Apresepsi- } \\
\text { motivasi } \\
\text { d.Pembagian } \\
\text { Kelompok } \\
\text { e.Tujuan } \\
\text { Pembelajaran }\end{array}$ \\
\hline 2 & $\begin{array}{l}\text { Penya } \\
\text { jian }\end{array}$ & $\begin{array}{l}\text { Langkah- } \\
\text { langkah } \\
\text { pembelaja } \\
\text { ran model } \\
\text { PBL }\end{array}$ & $\begin{array}{l}\text { a..Mengorien } \\
\text { tasikan siswa } \\
\text { untuk belajar } \\
\text { b.Mengorgan } \\
\text { isasikan } \\
\text { siswa untuk } \\
\text { belajar } \\
\text { c..Membantu } \\
\text { penyelidikan } \\
\text { kelompok } \\
\text { d..Mengem } \\
\text { bangkan dan } \\
\text { mempresenta } \\
\text { sikan hasil } \\
\text { karya } \\
\text { e..Menganali } \\
\text { sis dan } \\
\text { mengevaluasi } \\
\text { proses pemecahan } \\
\text { masalah }\end{array}$ \\
\hline
\end{tabular}




\begin{tabular}{|l|l|l|l|}
\hline 3 & Penutup & $\begin{array}{l}\text { Penutup } \\
\text { dan }\end{array}$ & a. \\
& & Merangkum \\
& & evaluasi & materi \\
& & pembelaja & b..Evaluasi \\
& ran & hasil belajar \\
& & c. Pemberian \\
& & tugas \\
& & d. Salam dan \\
& & & doa \\
\hline
\end{tabular}

Tabel 3. Lembar Pengamatan/observasi pelaksanaan model pembelajara PBL

Pada dasarnya desain penelitian ini mengikuti urutan pelaksanaan kegiatan penelitian tindakan kelas dengan desain model siklus. Dengar alur sebagai berikut :

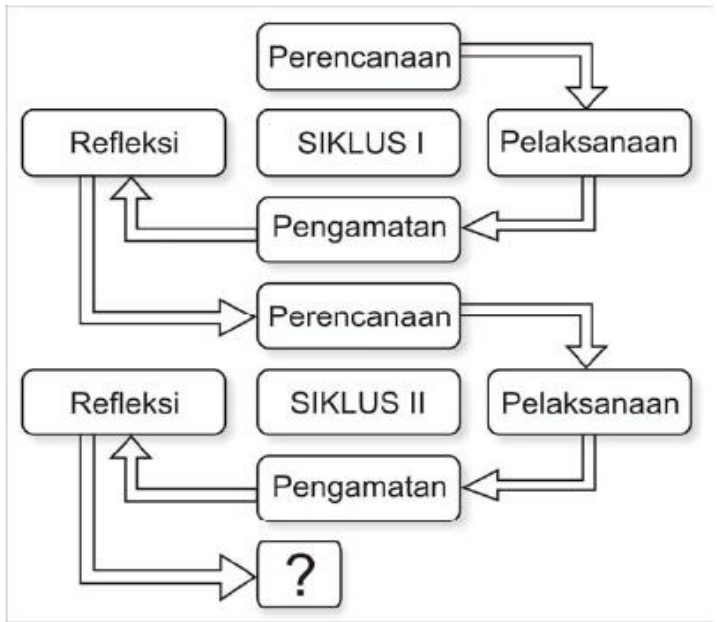

Rencana (Plan)

Membuat rencana tindakan untuk melakukan peningkatan keaktifan siswa. Hal-hal yang perlu disiapkan dalam prencanaan antara lain :

1. Menetapkan jadwal penelitian

2. Menyusun perangkat pembelajaran, yaitu Rencana Pelaksanaan Pembelajaran dengan model pembelajaran Problem Based Learning (PBL) dan Lembar kerja Siswa

3. Mempersiapkanalat/bahan yang digunakan untuk setiap pertemuan

4. menyusun lembar pengamatan yaitu lembar Aktivitas siswa tiap pertemuan dan lembar pelaksanaan model pembelajaran Problem Based Learning (PBL)

Pelaksanaan Tindakan

Tahap tindakan dilaksanakan oleh guru berdasarkan isi rancangan yang telah disusun. Tahap pelaksanaan tin dakan berupa penerapan model PBL selama proses pembelajaran. Dalam pelaksanaan tindakan peneliti sebagai guru di kelas dibantu oleh teman sejawat yang bertindak sebagai pengamat/observer. Proses belajar mengajar dalam pelaksanaan tindakan sebanyak empat kali pertemuan, yang setiap siklusnya terdiri atas dua pertemuan.

Pengamatan (Observasi)

Pada tahapan ini, peneliti dan observer mengambil data keakti fan siswa selama pembelajaran.

Pengambilan data dilakukan melalui pengamatan keaktifan siswa sesuai instrumen penelitian dan pengamatan pelaksanaan model pembelajaran PBL. Pengamatan dilakukan oleh peneliti dibantu teman sejawat/observer.

\section{Refleksi}

Tahap reflesksi merupakan kegiatan mencermati dan menganalisis secara keseluruhan tindakan yang dilakukan. Analisis dilakukan berdasarkan data yang telah dikumpulkan selama observasi. Tahap ini juga mengevaluasi kendala dan hambatan yang telah dikumpulkan selama observasi. Tahap ini juga mengevaluasi

Kendala dan hambatan yang ada selama proses pembelajaran yang digunakan sebagai bahan pertimbanagan dalam merencanakan pelaksanaan siklus berikutnya.

Teknik pengumpulan data yang digunakan adalah sebagai berikut:

a. Pengamatan bertujuan untuk melihat aktivitas siswa, aktivitas siswa diamati oleh teman sejawat/observer

b..Pengamatan bertujuan untuk mengamati pelaksanaan model 
pembelajara Problem Based Learning dalam pembelajaran oleh teman sejawat/observer.

Penelitian yang dilakukan peneliti adalah penelitian data kualitatif

Analisis data hasil observasi kegia tan siswa dalam penelitian ini

Adalah merefleksikan hasil pengamatan berupa keaktifan siswa yang dianalisis dengan langkahlangkah berikut:

1) Berdasarkan data hasil observasi, nilai keaktifan pada tiap-tiap indikator penelitian diolah dengan menjumlahkan siswa yang aktif tiap indikator penelitian 2) Setelah diperoleh jumlah siswa tiap indikator penelitian, selanjutnya dibandingkan dengan total jumlah siswa dalam satu kompetensi keahlian

3) Menghitung persentase keaktifan sis wa dengan rumus :

Persentase $=\sum \underline{\text { Siswa IP }} \quad$ X 100\% $\sum \frac{\text { Siswa IP }}{\text { Total Siswa KK }}$

IP = Indikator Penelitian

$\mathrm{KK}=$ Kompetensi keahlian

Dengan kriteria Persentase:

$81-100=$ Sangat Baik

$61-80=$ Baik

$41-60=$ Cukup Baik

$21-40=$ Kurang Baik (Arikunto, Suharsimi 2010: 200).

\section{PEMBAHASAN}

Siklus I dilakukan terdiri atas dua kali pertemuan. Dalam setiap pertemuan siswa diberi tugas kelompok yang harus diselesaikan dalam pertemuan tersebut. Aktivitas siswa diamati oleh seorang penulis dibantu oleh teman sejawat/observer dengan menggunakan instrumen pengamatan aktivitas siswa. Penerapan model Problem Based Learning tepat atau tidak untuk tujuan meningkatkan keaktifan siswa juga diamati oleh seorang teman sejawat/observer dengan menggunakan instrumen pengamatan/observer pelaksanaan model pembelajaran base learning. Setelah dua kali pertemuan pembelajaran (siklus 1) maka penulis merefleksikannya.

Berdasarkan hasil pengamatan pada siklus I model pembelajaran Problem Based Learning telah dilaksanakan secara baik berdasarkan sintaks model pembelajaran model base learning tersebut. Keaktifan siswa ditunjukkan oleh data prosentase pada pertemuan pertama dan kedua pembelajaran . Pada pertemuan pertama diperoleh data prosentase indikator penelitian aktivitas belajar siswa adalah sebagai berikut :

\begin{tabular}{|l|l|l|l|}
\hline NO & \multicolumn{1}{|c|}{$\begin{array}{c}\text { INDIKATOR } \\
\text { PENELITIAN }\end{array}$} & S1/P1 & S1/P2 \\
\hline 1 & Menyimak Guru & $90 \%$ & $94 \%$ \\
\hline 2 & Aktif bertanya & $61 \%$ & $68 \%$ \\
\hline 3 & Diskusi kelompok & $65 \%$ & $65 \%$ \\
\hline 4 & $\begin{array}{l}\text { Menyelesaiakan } \\
\text { laporan }\end{array}$ & $77 \%$ & $81 \%$ \\
\hline 5 & $\begin{array}{l}\text { Mengumpulkan } \\
\text { data }\end{array}$ & $68 \%$ & $71 \%$ \\
\hline 6 & $\begin{array}{l}\text { Melakukan } \\
\text { percobaan }\end{array}$ & $84 \%$ & $87 \%$ \\
\hline 7 & Aktif menjawab & $55 \%$ & $65 \%$ \\
\hline 8 & $\begin{array}{l}\text { Membuat } \\
\text { kesimpulan }\end{array}$ & $71 \%$ & $77 \%$ \\
\hline
\end{tabular}

S1/P1 = Siklus 1/Pertemuan1

Tabel 4. Data hasil pengamatan prosentase tiap indikator penelitian

Artinya siswa terlibat secara aktif dalam proses pembelajaran. Keterlibatan siswa ini bisa dilihat dari rata-rata keaktifan belajar siswa adalah adalah $74 \%$ yang termasuk kategori baik.

Siklus II dilakukan terdiri atas dua kali pertemuan. Dalam setiap pertemuan siswa diberi tugas kelompok yang harus diselesaikan dalam pertemuan tersebut. Berdasarkan hasil pengamatan pada siklus II model pembelajaran Problem Based Learning telah dilaksanakan secara baik berdasarkan sintaks model pembelajaran model base learning tersebut. Keaktifan siswa ditunjukkan 
oleh data prosentase pada pertemuan pertama dan kedua. Pada pertemuan pertama diperoleh data prosentase indikator penelitian keaktifan belajar siswa dalam belajar adalah sebagai berikut :

\begin{tabular}{|c|c|c|c|}
\hline $\begin{array}{l}\mathrm{N} \\
\mathrm{O}\end{array}$ & $\begin{array}{l}\text { INDIKATOR } \\
\text { PENELITIAN }\end{array}$ & $\mathrm{S} 2 / \mathrm{P} 1$ & $\mathrm{~S} 2 / \mathrm{P} 2$ \\
\hline 1 & Menyimak Guru & $97 \%$ & $100 \%$ \\
\hline 2 & Aktif bertanya & $71 \%$ & $77 \%$ \\
\hline 3 & Diskusi kelompok & $74 \%$ & $81 \%$ \\
\hline 4 & $\begin{array}{l}\text { Menyelesaiakan } \\
\text { laporan }\end{array}$ & $87 \%$ & $87 \%$ \\
\hline 5 & $\begin{array}{l}\text { Mengumpulkan } \\
\text { data }\end{array}$ & $81 \%$ & $81 \%$ \\
\hline 6 & $\begin{array}{l}\text { Melakukan } \\
\text { percobaan }\end{array}$ & $94 \%$ & $94 \%$ \\
\hline 7 & Aktif menjawab & $74 \%$ & $84 \%$ \\
\hline 8 & $\begin{array}{l}\text { Membuat } \\
\text { kesimpulan }\end{array}$ & $84 \%$ & $90 \%$ \\
\hline
\end{tabular}

Tabel 5. Data hasil pengamatan prosentase tiap indikator penelitian

Artinya siswa terlibat secara aktif dalam proses pembelajaran keterlibatan siswa ini bisa dilihat dari rata-rata keaktifan siswa adalah adalah $85 \%$ yang termasuk dalam kategori sangat baik, ternyata terjadi peningkatan keaktifan siwa dari siklus I ke siklus II bisa dilihat dari rata-rata prosentase siklus I dan siklus II yaitu dari $74 \%$ menjadi $85 \%$.

\section{KESIMPULAN}

Berdasarkan hasil penelitian dan pembahasan dapat disimpulkan:

1. Keaktifan belajar siswa dalam pembelajaran termasuk kategori baik dengan rata-rata pada siklus I $74 \%$ dan sangat baik pada siklus II $85 \%$

2. Terjadi peningkatan keaktifan belajar siswa dalam pembelajaran, yaitu dari $74 \%$ menjadi $85 \%$.

3. Model pembelajaran Problem Based Learning terbukti dapat meningkatkan keaktifan siswa di kompetensi keahlian $\mathrm{X}$ Otomatisasi dan Tata kelola Perkantoran SMKN2 PPU

\section{DAFTAR PUSTAKA}

Arends, Richard. (2008). Learning to Teach. Penerjemah: Helly Prajitno $\&$ Sri Mulyani. New York : McGraw Hill Company.

Arikunto, Suharsimi, 2006, Metode penelitian : Prosedur Penelitian Suatu Pendekatan Praktek, Rineka Cipta, Jakarta

Djamarah, Syaiful Bahri (2008). Psikologi Belajar. Jakarta Rineka Cipta

Delisle dalam Abidin (2014: 159) http://repository.unpas.ac.id/12845/ 4/BAB\%20II\%20benar.pdf

Eveline Siregar, Hartini Nara. (2011). Teori Belajar dan Pembelajaran . Bogor:Ghalia Indonesia

Hanafiah, Nanang \& Cucu Suhana. 2010. Konsep Strategi Pembelajaran. Bandung: Refika Aditama.

Mieke Miarsyah, dkk.2008. Ilmu Pengetahuan Alam untuk SMK dan MAK Kelas XII. Jakarta: Erlangga

Oemar Hamalik. (2008). Proses Belajar Mengajar. Jakarta: Bumi Aksara.

Sardiman. (2012). Interaksi dan Motivasi Belajar Mengajar. Jak arta: PT Raja Grafindo Persada

Sudarman. (2007). Problem Based Lear ning: Suatu Model Pembelajaran u ntuk Mengembangkan dan meningkatkan Memecahkan Masalah.

Ekosistem,http://woocara.blogspot. com/2015/02/pengertian-ekosistemkomponen-dantipe.html\#ixzz53Zgnl0g 